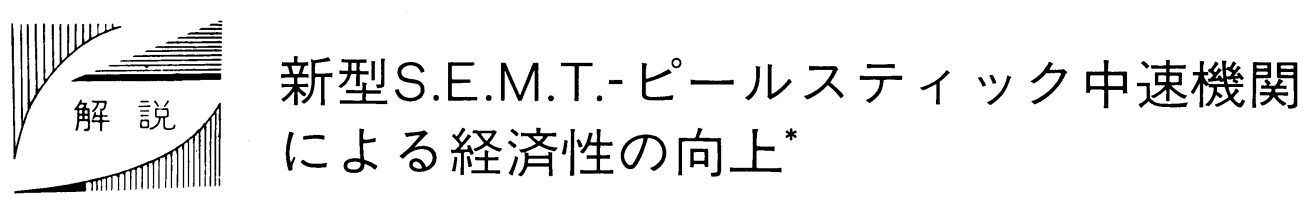

\author{
( 本稿は, 本年 2 月 5 日丸ノ内ホテル(東京), 同 7 日オリ \\ エンタルホテル(神戸)で開催された本学会月例講演会の講 \\ 演要旨石川島播磨重工業(株)，日本鋼管(株)，(株)新潟 \\ 鉄工所三社が共同翻訳したものである.
}

$$
\text { イボン・ルディゼス**. ミッシェル・ボンッール** }
$$

運航経費中の燃料費比率の高騰に対処するため, ディ 一ゼルエンジン設計者は燃料消費率の低減に対して，あ らゆる努力を傾注してきた。ユーザや造航所が新しいエ ンジンを選択する際に，まず考虑するのは燃料消費率で あり，ての点は避けて通れない問題である. エンジンメ 一力間の厳しい競争に扰いて, 低速機関はスーパーロン グストローク化で低燃費を達成しているが，中速機関む 魅力あるあのとするために，低速機関と同様の性能を達 成せねばならない。

低質油を問題なく使用できることも設計目標の一つで ある.中速機関については既に数年来の実績から低質油 燃燒が可能なととは実証されており，PC 形機関でも使 用する燃料油質が低下する傾向にあるが，運航実績から は，ほとんど重大な問題は生じてない。摩耗は良質油を 使用した場合之同梯に良好であり，ISO 規格案以上の シリカを含んだ油を使った時や，比較にならない程不適 当なブレンド油を使用した時に発生した若干の不具合は どの様なディーゼルエンジンにあ共通して起とりうる問 題である.てのように，今日，4 サイクル中速機関にお いてあ低質油使用が可能なととは明らかであり，低速機 関より劣っているというととは当たらない.

メンテナンス経費の低減むユーザから強く要望されて いるととである.乙れは信頼性の向上により達成される あのであり，S.E.M.T. 社も目標の一つとして数年来研 究してきているが, シリンダ数の減少がまず第一である. PC 形機関の納入実績から見ると, 現状はシリンダ数の 少ないL形機関の 1 機 1 軸船が増加しており，乙の傾向 からあ, このユーザ要求が裏付けられている. 又更に, あう一つの強い要望は低質油低負荷運転に扔いて, 長時 間にわたり良好な運転性能を維持することである。

この様なユーザの諸要求に合致した先進的なエンジン を市場に提供するため, S.E. M. T. 社は広範囲の研究開 発を続けてきたが, その最重点の研究課題は燃料消費率 の低減である.コンピュータによる諸解析の裏付けに基

* 原稿受付 昭和 60 年 4 月 11 日

** SEMT 2, QUAI DE SEINE BOITE POSTALE75 93202 SAINT-DENIS CEDEX 1 FRANCE
づき空気過剩率，圧縮比，燃焼最高圧力，噴射タイミン グ，燃焼室形状，ストローク/ボア比等の諸要因の影響 を評価するとともに，数多くのテストを実施した.

これらの研究の結果, 在来の PC 形機関を補完するエ ンジンとして, 新しく 3 機種の中速機関を開発し，まず L形機関を製作するとととした．そのうちの 2 機種は既 存エンジンをべースとしたあのであり, 残り 1 機種は全 くの新型である.

\section{1. 基本概念とその結果}

1.1 過給方式 いわゆる MPC 過給方式(モジュ ラーパルスコンバータ方式)を標準としている．乙の過 給システムは数年来, 在来の PC 形機関に適用して完全 に期待に沿う稼動実績を示している. との MPCシステ ムの有利性は図 1 で示すバィパス方式を併用するととに より更に增大する．その特徵は，

一部分負荷での空気過剩率の増加

一サージングの危険を伴わない最適な過給機のマッチング 一常用出力で最良の性能となる過給機のマッチングが選

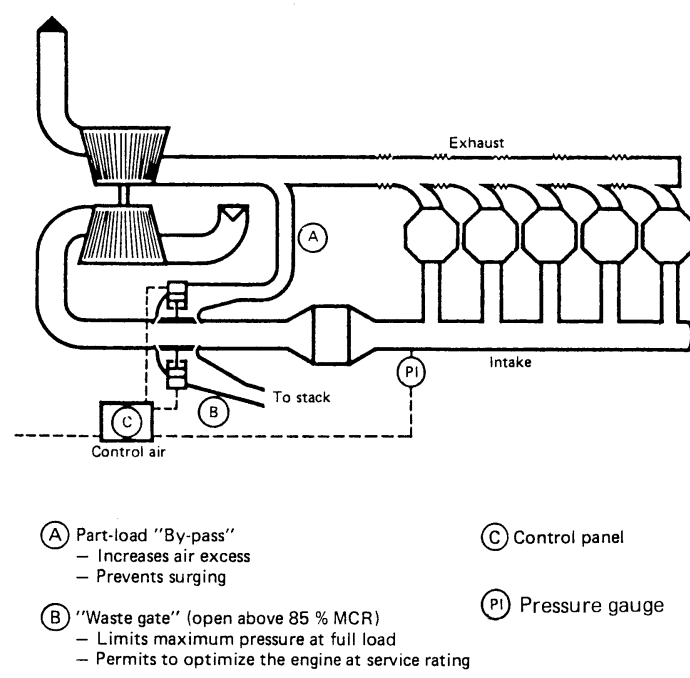

図1 バイパス付過給方式 
定され，しかも，全負荷出力までの運転が可能となる （それは常用出力から定格出力まではバイパスにより 燃焼最高圧力を規定值に押えることができるからであ る).

本システムの二つのバイパス弁 A, B (弁 A は低負荷で 開き,一方弁 Bは高負荷で開く, 常用出力では両弁とも 閉じている)は燃料ラックの作動によって完全に自動制 御される.

過給機は最新の BBC-VTR 4 A シリーズである. この 過給機は効率の向上を図ったあのであり, 又無冷却ケー シングあ採用している.PC 30 及び PC 40 形では軸方向 ガス流入形の過給機を採用しているため，コンパクトな 配置となり，合わせて過給機回りの高さも減少している.

\section{2 燃焼効率改善のための基本的要因 PC4} 及び PC 2-6 形のテストエンジンで行われた系統的な研 究から, 燃料消費率を最小にする基本的パラメータを求 め, 次の如く, 新しいエンジンの設計指針を得た.

一燃焼最高圧力と压縮压力の最適比率は最高圧力に伴っ てわずかに増えるが， 1.4 から 1.6 の間に存在する (図 2).したがって, 今まで PC2-6, PC4-2 形では圧 縮比は 11.5 と 11.8 であったが, PC 20, PC40 形では 13.4，14.0に増大した(PC 30 形は 15.3).

一熱効率は燃焼最高圧力と共に上がり， 170～180 バー ルにて最高となるので, 142 バールの最高压力を PC 20 形は 150 バールに, PC 40 形は 155 バールに高め

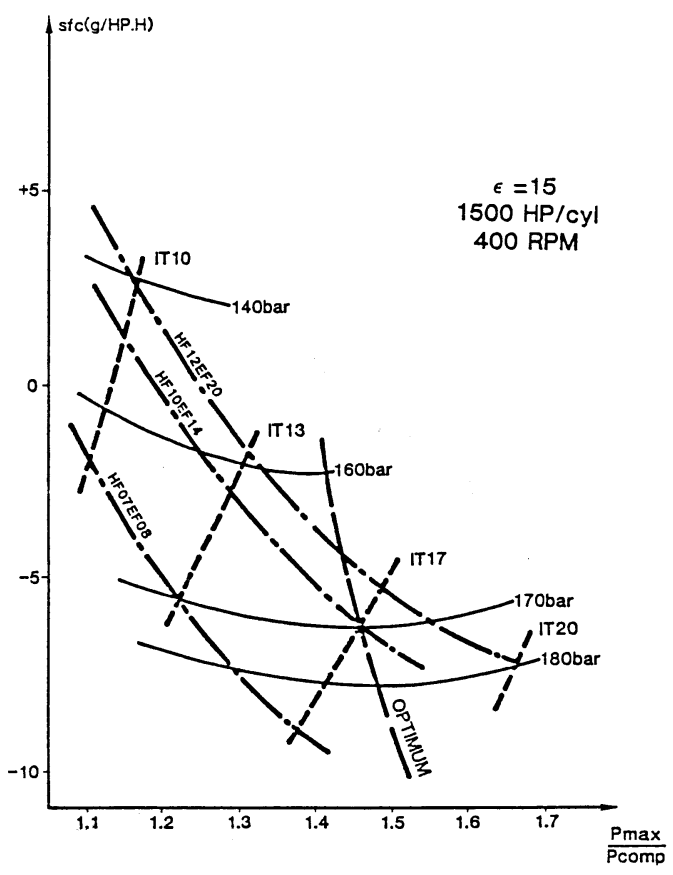

困 24 PC4 形テストエンジンの $P_{\max } / P_{\text {comp }}$ 最適化テスト
た（PC 30 形は 180 バールとした）.

ーディレーティングは燃費低減の有効な手法である.した がって，10\%ディレーティングの経済仕様機関 “E” 形 を導入して, $2 \mathrm{~g} / \mathrm{PS}-\mathrm{h}$ の燃費低減を可能とした。

1.3 ストローク/ボア比 ストローク/ボア比 を増し，ピストンスピードを同一に保った上で，その分 エンジン回転数を下げることは, S. E. M. T. 社でも数年 前から考えていた．噴射期間は数ミリセカンドであり， 燃焼期間屯同程度に維持されるという想定に基づくと, ストロークの大きいエンジンを低速運転した場合，作動 サイクル後半の定温膨張の領域での効率を改善でき, こ れによって燃料消費を減少することができる.

定格回転数 $1,000 \mathrm{rpm}$ のPA6 形をロングストローク 化したPA 6-CL形が 1982 年開発され, 種々のテストの 結果, 燃料消費率は $7 \mathrm{~g} / \mathrm{PS}-\mathrm{h}$ 低減された. 同様なアプ ローチを中速機関にあ採用することが決定し，その目的 のため改造された PC 2-6 及び PC 30 形のテストエンジ ンが実験に供された.

・図 3 に，2PC2-6 形テストエンジンでの計測結果を 示す (PC2-6CL形はストローク/ボア比を 1.15 から 1.37 に増加したあのである)。な拉，図の符号のうち， P 3 は給気圧力, T 4 はタービン入口排気温度, T 5 は タービン出口排気温度, $s f t$ は燃料消費率を示してい る.

一燃焼最高圧力を 7 bar 上昇した場合は燃料消費率が 12
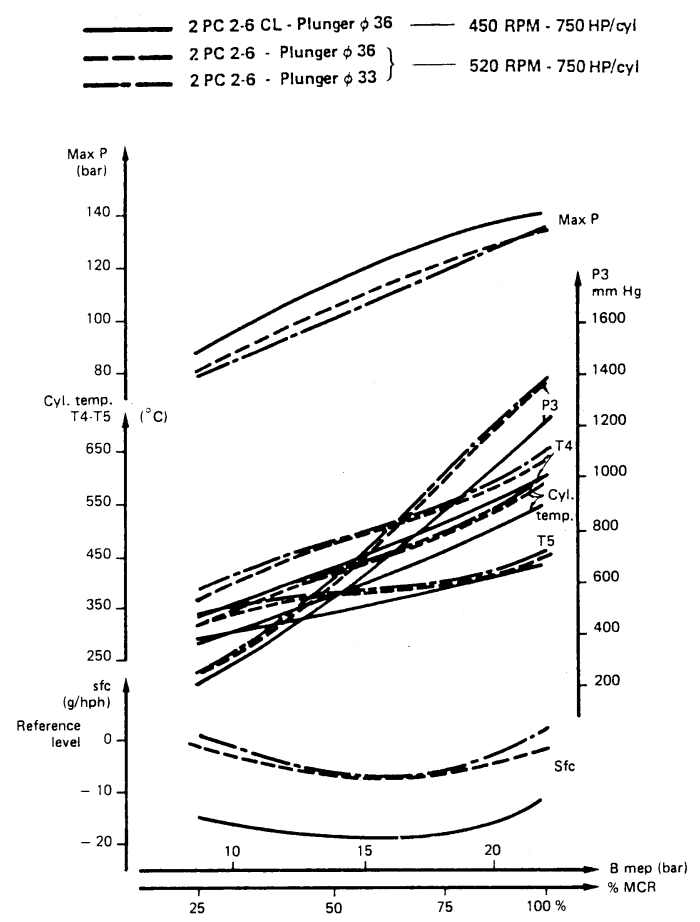

困 3 PC2-6形とPC2-6CL形(ロングストローク) 機関の性能比較 (プロペラ法則による)

昭和 60 年 11 月 
$\mathrm{g} / \mathrm{PS}-\mathrm{h}$ 減少した. 従来之同一の燃焼最高圧力の場 合, 燃費改善分は $10 \mathrm{~g} / \mathrm{PS}-\mathrm{h}$ ，すなわち $7 \%$ であっ た.

一排気温度はシリンダ出口と過給機入口で各々 $40^{\circ} \mathrm{C}$ 低 下しており, 燃料消費の低減とよく一致している.

・PC 30 形ではストロークを $450 \mathrm{~mm}$ より $600 \mathrm{~mm}$ に伸 ばした結果（ストローク/ボア比は 1.41), 燃料消費率 は $8 \mathrm{~g} / \mathrm{PS}-\mathrm{h}$ ，すなわち $6 \%$ 改善された(図 4).

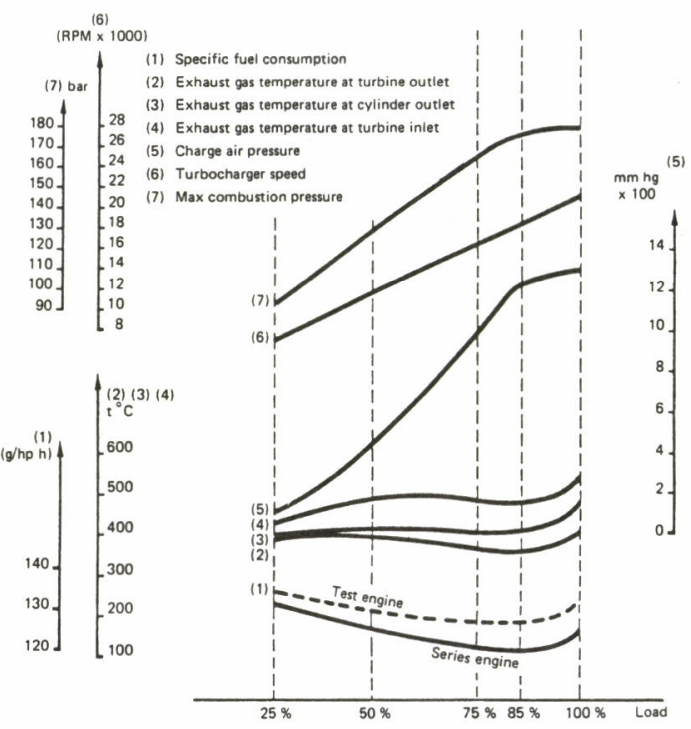

図 4 4 PC 30 形機関の運転成績 （プロペラ法則による）

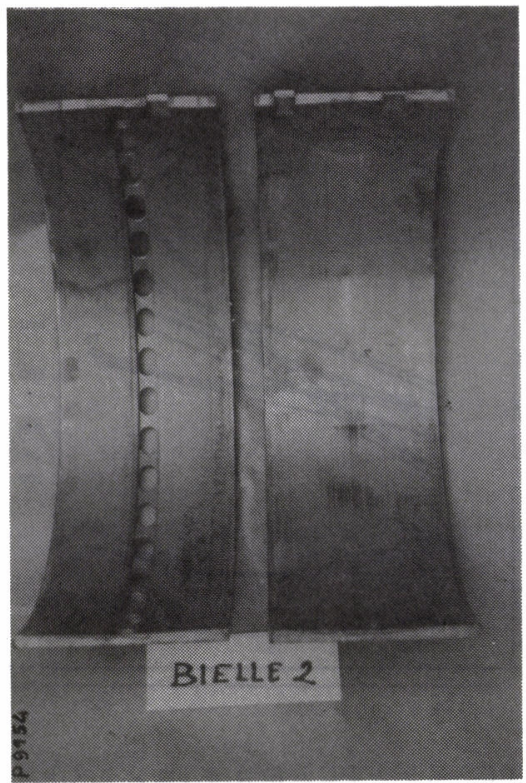

図 5-1 PC 30 形のクランクピンメタル
1.4 試験結果 PC 20 及び PC 40 形は，既に実 績のある PC 2-6 及び PC 4-2 形をベースにロングスト ローク化している.一方，PC 30 形は，全く新たに設計 された機関であり，その開発過程において種々の試験を 行う必要があった.

PC 30 形の試験は，1983 年 1 月に開始した. 試験開 始当初に, 設計変更を必要とするいくつかの不具合が見 られた他は, 大きな不具合はなかった。しかし, 性能面 では燃焼室形状, 圧縮比, 空気過剩率, 噴射系, バルブ タイング，ストローク等の改善及び最適化を行っており， これにより試験開始当初より約 $20 \mathrm{~g} / \mathrm{PS}-\mathrm{h}$ の燃料消費 率の低減を達成した. 1984 年 10 月現在の総運転時間は, 300 時間の C 重油全負荷運転を含み 1,000 時間に達して おり, 現在む引き続き試験を行っている.

主要部品開放時の状況を図 5 に示す.試験に使用した $\mathrm{C}$ 重油の性状を表 1 亿示す. 燃焼室主要部品の温度測定 結果は図 6 に示すように, 在来型機関の測定結果と同レ ベルとなっている.

性能向上試験を行う一方, 燃焼最高圧力の上昇に伴う 信頼性向上に関する試験を行った. 摩耗したシリンダラ イナ(船主の廃棄品) を $4 \mathrm{PC} 4$ テストエンジンに組み込 んだ.シリンダライナの摩耗状況は機関長手方向 ( F-A 方向) $0.68 \mathrm{~mm}$, 機関横方向 (P-S方向) $1.37 \mathrm{~mm}$, シリ ンダライナ楕円度 $0.65 \mathrm{~mm}$ であった.テストエンジンの 連続最大出力は $1,650 \mathrm{PS} / \mathrm{cyl}$ であったが, 試験では機 関負荷を $950 \mathrm{PS} / \mathrm{cyl}$ から 1,850 PS/cyl まで, 各負荷 での運転時間を 30 分として周期的に変動させた. 試験 は, シリンダ冷却水の機関出口温度を $85^{\circ} \mathrm{C}$ から $75^{\circ} \mathrm{C}$ に 低下させ，更に給気量を減少することにより熱応力を増

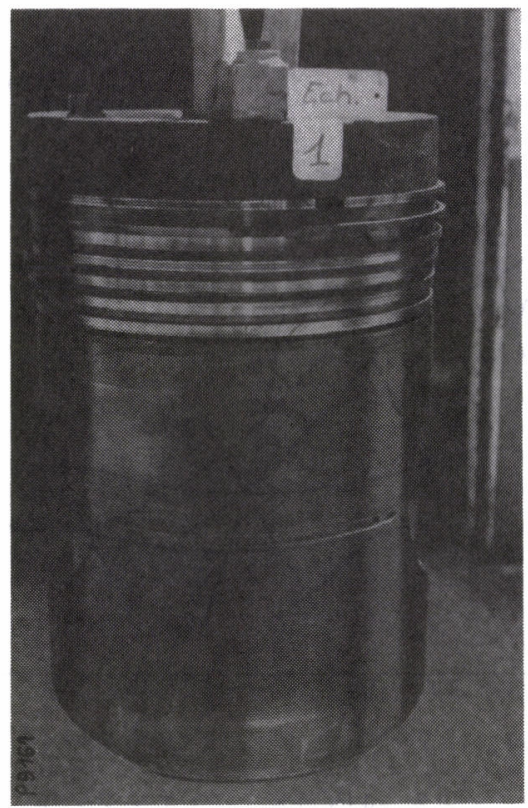

困 5-2 PC30形のピストン 
表 1 SEMT テストエンジン用燃料油の分析值
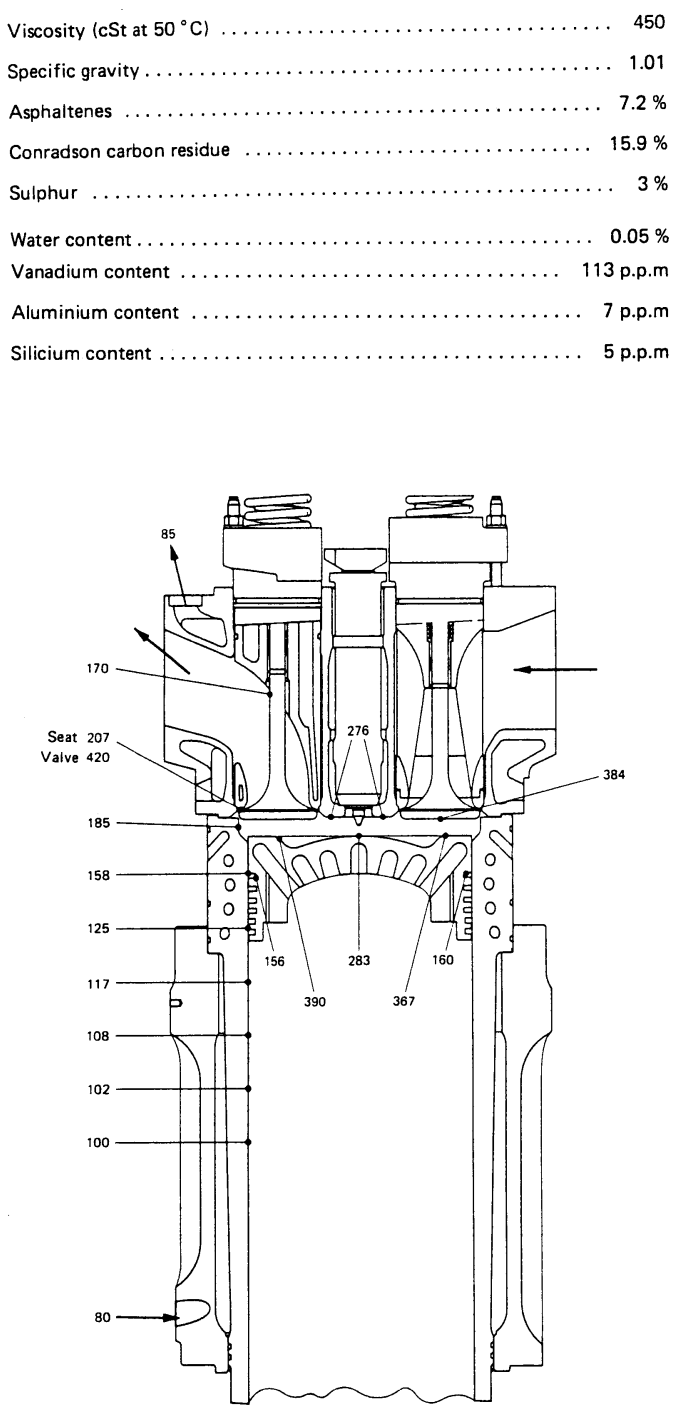

図 6 PC 30 形機関燃焼室周りの部品の温度計測 (全力 $736 \mathrm{~kW} / \mathrm{cyl}$ にて, 単位 ${ }^{\circ} \mathrm{C}$ )

大させた過酷な運転状況で行った，運転時間は 180 時間 にわたり，燃焼最高圧力は 160 bar が記録された. 運転 中に当該シリンダに何ら異常は認められず, 又, 試験後 の開放点検の結果，ピストンの表面状況及びピストンリ ングのシール状況あ良好であったととを確認した.

\section{5 出力回収システム(Recovery Power}

Turbine 高効率過給機の採用により, 利用可能な 給気量が増加し, 給気と排気の圧力差も増加した. この 結果, 燃料消費率の低减を図ったにもかかわらず，排ガ スエネルギは機関必要量に対し十分に余裕がある. この 余楼ガスエネルギを活用して，より一層の低燃費化を図 るために出力回収タービンをクランク軸に機械的に結合

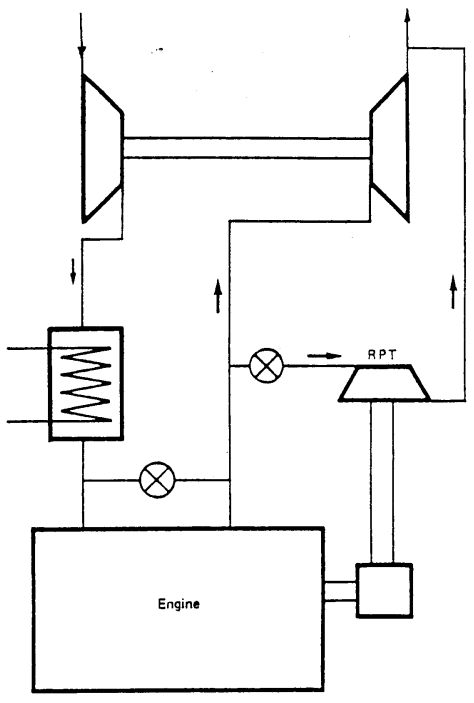

図 7 出力回収タービン (R.P.T. ) 配置

した出力回収システム (R.P.T.) を開発した（図 7). R.P.T. を利用して低燃費化を効率よく達成するために は，排気の圧力をより高く選ぶ必要がある.すなわち， R.P.T.を利用しない場合に比べて, タービンノズルリ ング面積を小さくする必要がある. 連続最大出力の $75 \%$ 以下の部分負荷では，排気ガスの供給弁を閉め, R. P.T. を作動させないが，常用出力域において供給弁を開け， R.P.T. を作動させる. この結果，過給機は機関出力に より 2 種類の異なった作動域を持つととになる.すなわ ち,

一部分負荷では排気圧及び給気压とも上昇する.乙れは， 低負荷域で効率の良い特性をむつ過給機を使用するこ とと同じことであり，燃料消費率が低减する．乙の作 動域においては, 前述のバイパスシステムによりサー ジングを回避することができる.

- R.P.T. を利用する常用出力域では，次の二つの結果 をあたらすととになる。

・第一に, R.P.T.により回収される動力を, 機械的 エネルギとしてクランク軸に還元する.

・第二に, 過給機は低圧の給気圧及び排気圧で駆動さ れるため常用出力域での燃焼最高圧力の過度の上昇 を防ぎ, 正常な值に保つ.

4PC4-2 テストエンジンで得られた性能を図 8 亿示 す. 燃料消費率は高負荷域にて $3 \%$, すなわち, $4 \mathrm{~g} / \mathrm{PS}$ - $\mathrm{h}$ 低減され, 一方, 部分負荷では $4.5 \%$, すなわち, $6 \mathrm{~g}$ /PS-h 低減され，更に，空気過剰率屯大幅に改善され た. R.P.T.はPC 30 及びPC 40 形にオプションとして 装備される. 参考図として， R.P.T. を装備した PC 4 形の外形困を図 9 に示す. R.P.T. を装備しても, 機関 駆動ポンプを取付けることができる. 


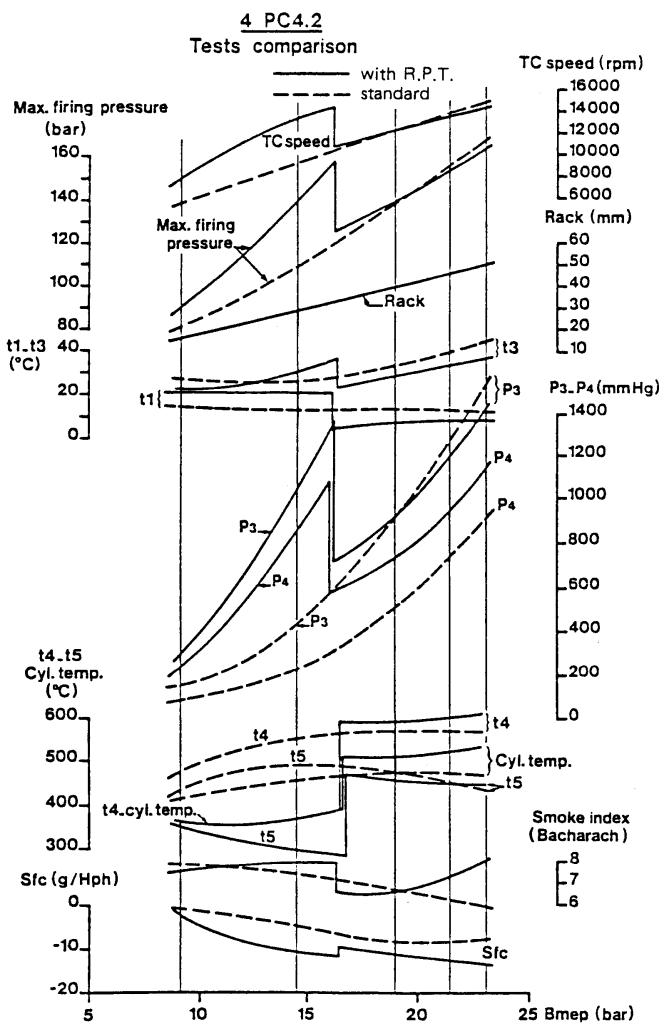

困 8 4PC4-2 形テストエンジンにおける標準仕様 と出力回収タービン付との運転成績比較
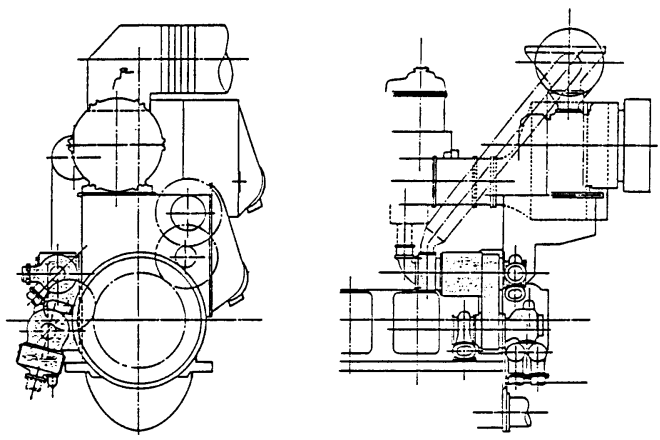

図 9 出力回収タービンを取付けた PC 4 形機関

\section{PC 形機関の新しい出力範囲}

前述の試験結果に基づき，更に市場の二ーズを考慮し， 表 2 の 3 機種を新シリーズとして追加し，その燃料消費 率を表 3 亿，組立断面図を図 $10 ， 11 ， 12$ 亿示す。 L形 機関に引き続き，V形機関の設計を進める予定である。

新型機関の主な設計上の特徵

新型 PC 機関は，基本的には，在来型機関の設計方法 が受け継がれており，構成部品の機械応力は在来型機と 同様十分に安全なレベルに保つととを原則とし，しかも いくつかの部品については，その熱応力を減少させてい る.ピストン, 連接棒及びクランク軸等の重要部品はコ ンピュータによる応力解析を適用して設計している.

在来型機関の主要部品との主な相違点及び新型機関に 採用した設計上の主な特徵は以下のとおりである。

一架 構 架構は一体溶接構造とし, クランク軸を懸吊 する思想を引き継いでいる．PC 20 形のL形機関につ

表 2 新形 $\mathrm{PC}$ 機関の要目

\begin{tabular}{|c|c|c|c|}
\hline 形 式 & PC 20 & PC 30 & PC 40 \\
\hline シリンダ径 $\mathrm{mm}$ & 400 & 425 & 570 \\
\hline ストローク $\mathrm{mm}$ & 550 & 600 & 750 \\
\hline 回 転 数 $\mathrm{rpm}$ & 450 & $428 / 450$ & 350 \\
\hline $\begin{array}{ll}\text { 出 } & \text { 力 } \\
& \mathrm{PS} / \mathrm{cyl}\end{array}$ & 750 & 1,000 & 1,650 \\
\hline $\begin{array}{r}\text { 平均ピストン速度 } \\
\mathrm{m} / \mathrm{s}\end{array}$ & 8.25 & $8.6 / 9.0$ & 8.8 \\
\hline $\begin{array}{r}\text { 平均有効压力 } \\
\mathrm{kPa}\end{array}$ & 2130 & $2425 / 2305$ & 2175 \\
\hline $\begin{array}{r}\text { 燃焼最高压力 } \\
\mathrm{MPa}\end{array}$ & 15 & 18 & 15.5 \\
\hline $\begin{array}{l}\text { 压 縮 比 } \\
\text { (E-仕様のとき) }\end{array}$ & $13.4(14.4)$ & $15.3(16)$ & $14(15)$ \\
\hline シリン ダ 数 & $6-7-8-9$ & $5-6-7-8-9$ & $5-6-7-8-9$ \\
\hline $\begin{array}{r}\text { シリンダ間距 離 } \\
\mathrm{mm}\end{array}$ & 740 & 750 & 980 \\
\hline
\end{tabular}

表 3 新形 PC 機関の燃料消費率

\begin{tabular}{|c|c|c|c|c|c|c|}
\hline 機関 形式 & \multicolumn{2}{|c|}{ PC 20 } & \multicolumn{2}{c|}{ PC 30 } & \multicolumn{2}{c|}{ PC 40 } \\
\hline $\begin{array}{c}\text { 出 仕 様 } \\
\mathrm{PS} / \mathrm{cyl} / \mathrm{rpm}\end{array}$ & $750 / 450$ & $\begin{array}{c}\mathrm{E} \text { 仕様 } \\
673 / 434\end{array}$ & $1000 / 450$ & $\begin{array}{c}\mathrm{E} \text { 仕様 } \\
900 / 435\end{array}$ & $1650 / 350$ & $\begin{array}{c}\mathrm{E} \text { 仕様 } \\
1485 / 338\end{array}$ \\
\hline $\begin{array}{r}85 \% \mathrm{MCR} \\
\mathrm{g} / \mathrm{PS}-\mathrm{h}\end{array}$ & 128 & 126 & 122 & 120 & 124 & 122 \\
\hline $\begin{array}{r}85 \% \mathrm{MCR}+\mathrm{RPT} \\
\mathrm{g} / \mathrm{PS}-\mathrm{h}\end{array}$ & & 118 & 116 & 120 & 118 \\
\hline
\end{tabular}

注：低位発熱量 $10200 \mathrm{kcal} / \mathrm{kg}$, マージン+3\%，機関駆動ポンプなしの場合. 


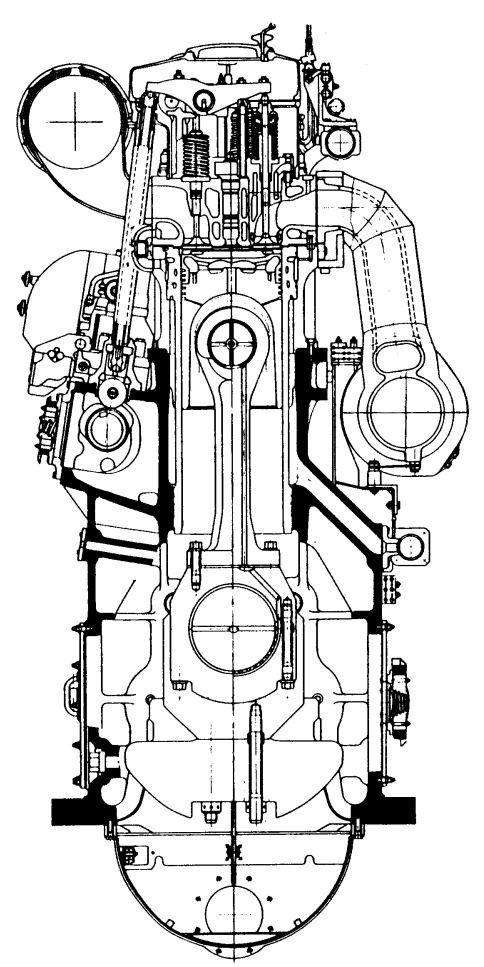

図 10 PC20 L 形機関断面図

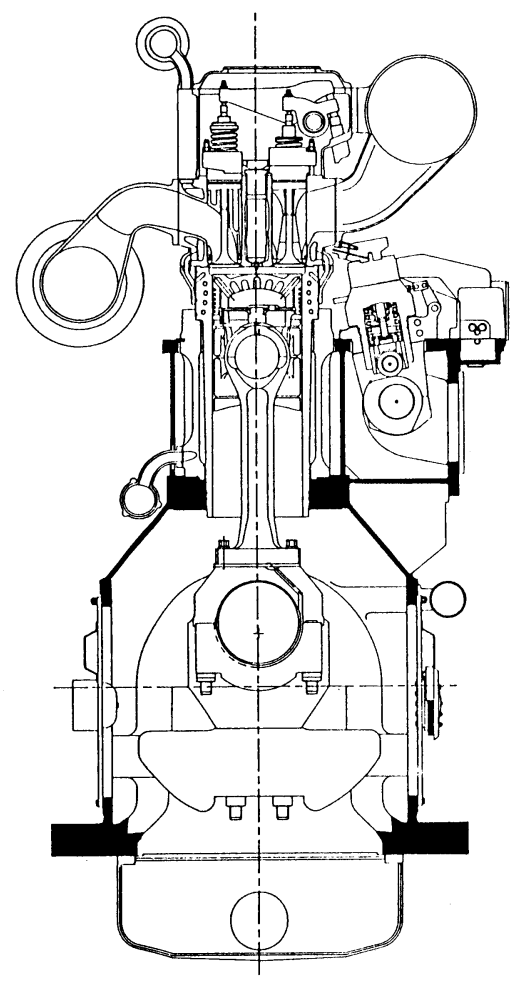

図 11 PC30 L 形機関断面図

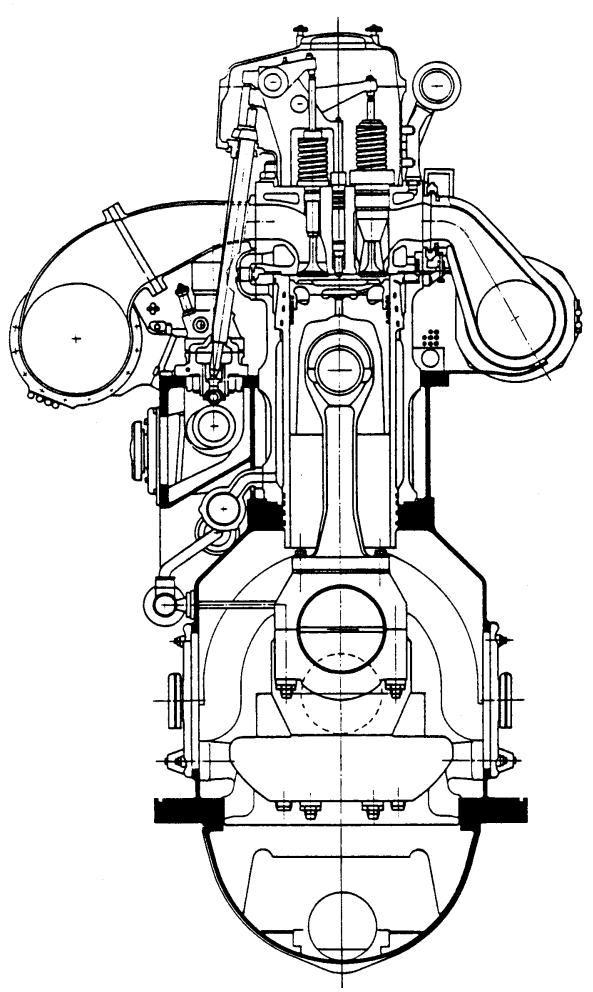

図 12 PC 40 L形機関断面困

いては, 1980 年にPC2-6 形にすでに導入したように 鋳鉄製架構の採用も可能である. 又, 各部の機械応力 は十分に安全なレベルであることを確認している（図 13).

ークランク軸 クランク軸は一体形鍛鋼製であり，機 械応力に対し十分な強度を持つよう配慮されている.

一軸 受軸受の油膜厚さ及び面圧は, すべてコンピ ュータにより解析し，十分安全サイドにあることを確 認している. 油膜厚さは計算上在来型に比べて全般に 厚くなっている.

一連接棒連接棒大端部は, 合せ面に斜め割セレーシ ョンを設けた在来型の 2 分割形から, 3 分割形とした. 3 分割形とした理由は，ピストン抜き高さを低く抑え ること及び機械加工を容易にすることの 2 点である.

王縮比を調整するために窒化鋼のシムを用いている (このシムは, 経済仕様機関 “E” 形で圧縮比を高め るために使用する). PC 30 形用連接棒の機械応力を Goodman 線図 (図 14) に示しているが, 応力は疲労応 力限度線以下に保たれている.

ーピストン 新型機関であ組立形ピストンを採用し， 機械的に十分な安全率を持たせるとともに，各機関と あ良好なピストン冷却が保持されるよう設計されてい る. PC 20 及び PC 40 形のピストンは, 鋼製の冠とア ルミ合金製のスカートの組立品であり, 段付ピンボス 


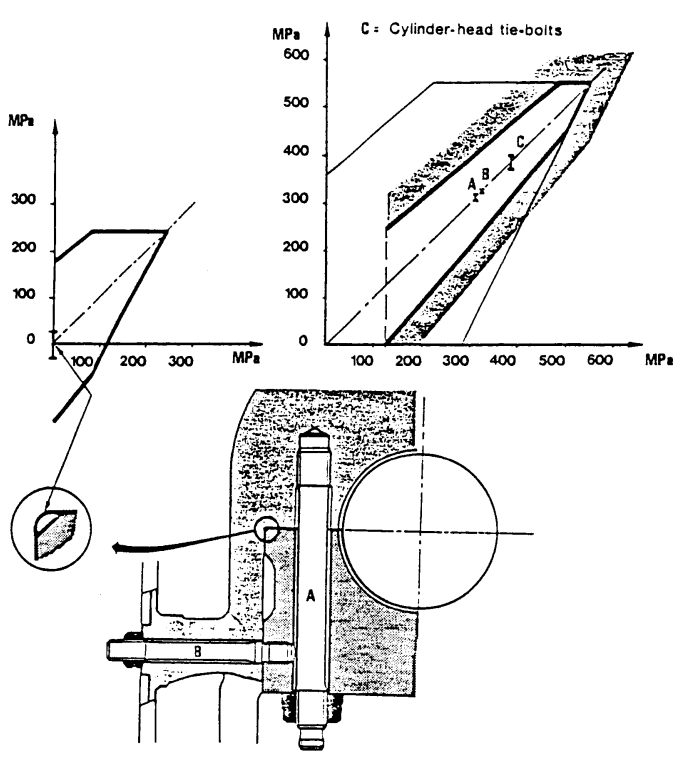

困 134 PC 30 形機関の主要部分の応力計測

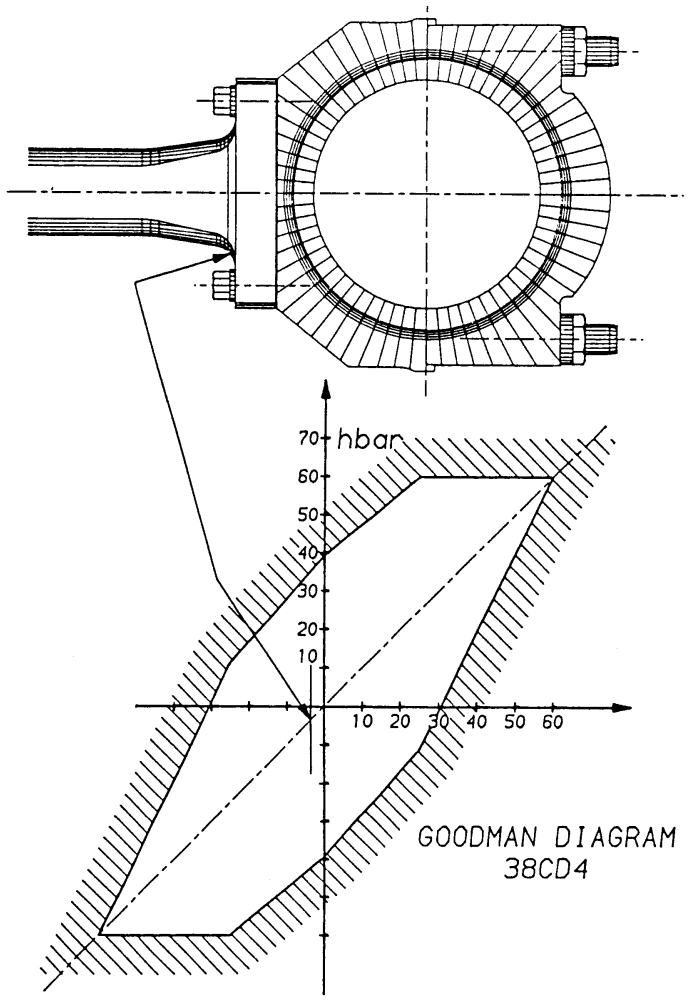

図 14 PC 30 形機関連接棒の機械応力

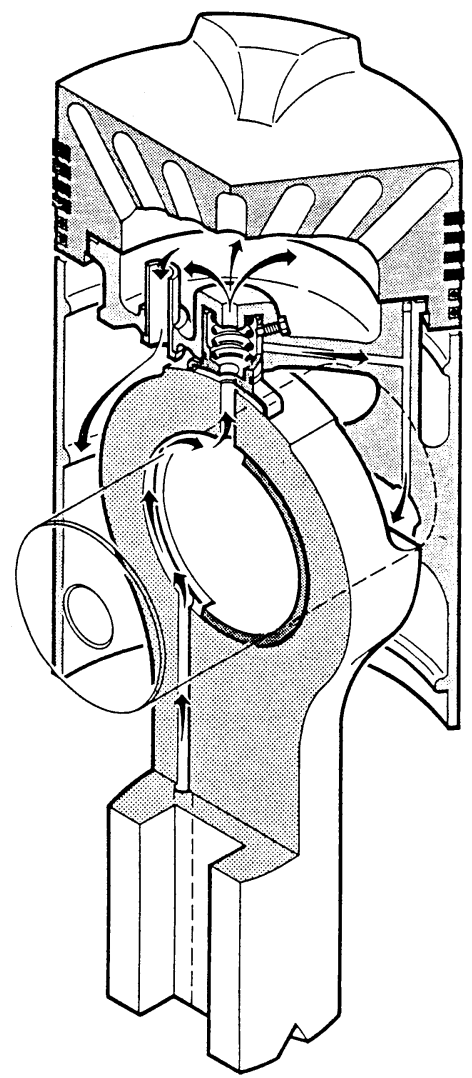

図 15 PC 30 形機関のピストン

部及びスカート部に強制潤滑を行っている.PC 30 形 のピストン（図 15)は，PC 2-5 形で使用実績のある鋳 鉄製のピストンを引き継ぎ，鋼製の冠と鋳鉄製のスカ トの組立形である. トップリング溝付近の温度は 160 ${ }^{\circ} \mathrm{C}$ であり, 最あ高温の部分であ $400^{\circ} \mathrm{C}$ 以下と, 通常の レベルとなっている(図6). PC 30 形のピストンピン は窒化鋼製で，油孔を持たない単純な中空軸とし，十 分な強度を保つことができる構造となっている.

ーシリンダヘッドＰC 30 形のシリンダヘッドは球状 黒鉛鋳鉄製であり，十分な強度を持っている(応力と しては，鋳鉄であ対応できるレベルにある). 給排気 弁はとあに弁箱を持った構造 (図 16) となっている. 燃料噴射弁はシリンダヘッド冷却水により冷却され， これまで取付けていた冷却水系統を廃止し単純化した。 新型機関の排気弁は,ナイモニック $80 \mathrm{~A}$ 製の弁棒，シ リンダヘッドとの気密方法及びシート部の冷却方法に 在来型機関の設計を引き継いでいる.

一燃料噴射ポンプ PC 30 形の燃料噴射ポンプは, $180 \mathrm{MPa}$ (1,800 bar)の燃料噴射厈力に耐えるように 設計した. プランジャの駆動機構はポンプ箱の中に収 められている. バレルには潤滑油ダムが設けられ，漏 洩燃料油による潤滑油の污れを防いでいる. このシス 


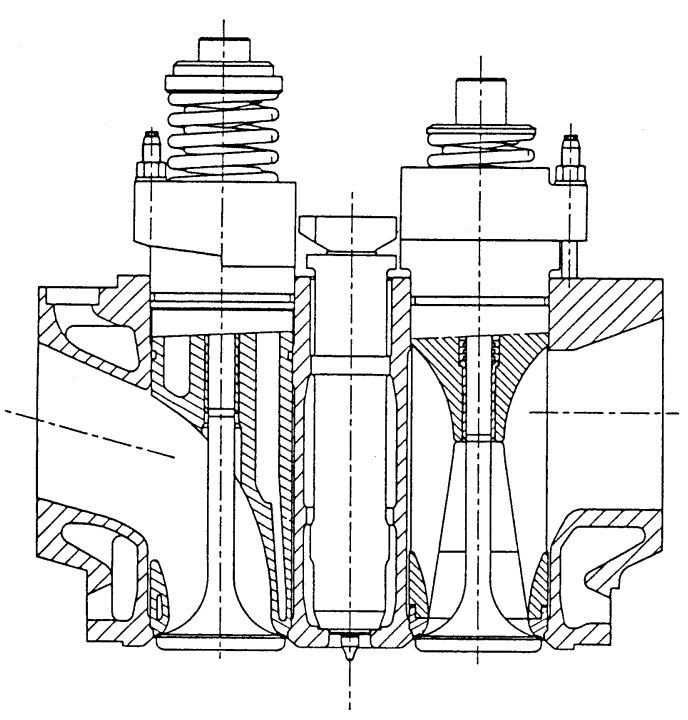

図 16 PC 30 形機関のシリンダ蓋
テムは，PA6 及びPC4 形で当初から採用されていた あのである.プランジャ, バレルは燃料噴射ポンプ頭 部を分解した後，上部から引き抜くことができる．燃 料噴射タイミングは, バレルフランジのシムにより調 整することができる.

一過給方式高効率過給機 BBC-VTR4Aシリーズ を採用した. 前述のバイパスシステムは，標準装備之 し, PC 30 及び PC 40 形にはオプションでR.P.T. を 装備する. 又, C重油使用時の低負荷性能改善のため, 2 段式の空気冷却器を標準装備とした.

\section{PC 形機関の運航実績}

新型機関の設計に際しては就航船における PC 形機関 の運航経験と成績を十分に考慮した。運航実績を以下に 要約する.

3.1 燃料油性状 PC 形機関に使用されている 燃料油の分析結果によれば，高粘度油を使用している機 関が大きく増加していることが分る. 比重, 残留炭素及 び硫黄分も増加しているがバナジウム分はそれほど増え ていない(図 17). 燃料油清浄装置が完備していれば, 最 近製造されたPC形機関は CIMAC 12 亿相当する粘度 $700 \mathrm{cSt}\left(50^{\circ} \mathrm{C}\right)$ の高粘度油まで使用するととが可能で

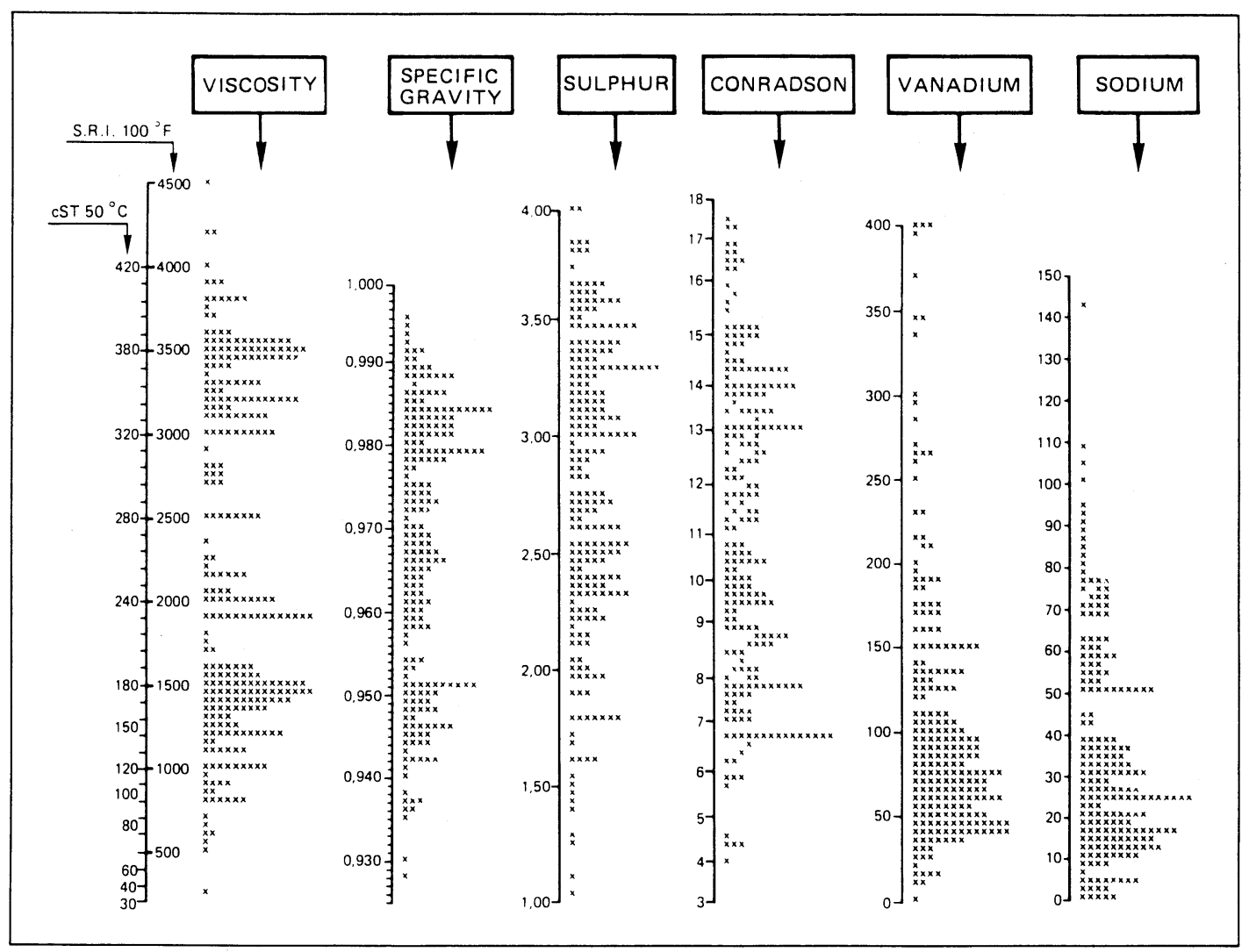

図 17 就航中の PC4 形機関の燃料分析值 
表 $4 \mathrm{PC}$ 機関の摩耗值 (C 重油使用)

\begin{tabular}{|c|c|c|c|}
\hline $\begin{array}{c}\text { Wear rate } \\
\text { (Expressed in } 1 / 100 \mathrm{~mm} \\
\text { per } 1000 \text { hours) }\end{array}$ & $P C 2-5$ & PC3 & PC4 \\
\hline Cylinder liner & $\begin{array}{c}\text { Prior to January } 1980 \\
5.35(1410) \\
\text { Since January } 1980 \\
2.55(1062)\end{array}$ & $2.10(842)$ & 2.47 (1139) \\
\hline \multirow{2}{*}{1 st piston ring } & $\begin{array}{c}\text { Prior to January } 1980 \\
5.90(409) \\
\end{array}$ & \multirow{2}{*}{$3.18(592)$} & \multirow{2}{*}{$2.58(541)$} \\
\hline & $\begin{array}{c}\text { Since January } 1980 \\
4.00(370)\end{array}$ & & \\
\hline \multirow{2}{*}{ 2nd piston ring } & $\begin{array}{c}\text { Standard Mo coated } \\
1.65(239)\end{array}$ & \multirow{2}{*}{ - } & \multirow{2}{*}{$1.35(387)$} \\
\hline & $\begin{array}{c}\text { Copper plated } \\
7.85(272)\end{array}$ & & \\
\hline 1st ring groove & $0.95(641)$ & 0.58 (392) & $0.47(394)$ \\
\hline 2nd ring groove & $0.50(533)$ & $0.22(373)$ & $0.30(392)$ \\
\hline
\end{tabular}

(Between brackets) : Number of cylinders

である.

\section{$3.2 C$ 重油使用時の部品摩耗值 (表 4)}

ーシリンダライナ 平均摩耗率は一般的に 0.02 0.03 $\mathrm{mm} / 1,000$ 時間の範囲にあり満足すべき結果と言え る. 1980 年以前に, ある特定の PC 2-5 形機関にて低 負荷運転による腐食摩耗を経験したことがある．との 腐食摩耗を助長したと思われるむのとして, 潤滑油の TBN 不足 (ASTM 2896 で, 20 以上とすべきである)， シリンダ冷却水低温度, 出入港及び増速時のシリンダ 冷却水温度制御不良が考えられる. 代表的な例を次に 示すと,

* $12 \mathrm{PC} 2-5 \mathrm{~V}$ 形 4 基搭載のカーフェリにて常時低負 荷運転を行い, 就航後 4,200 時間にて 2 基の摩耗率 は $0.05 \mathrm{~mm} / 1,000$ 時間となった. 本船の出入港及び 増速時の温度制御装置は作動不良にて, 機関起動後, ジャケット冷却水温度が低温のまま数時間運転され ていた。

上記のととから, 腐食摩耗はジャケット冷却水温度が 低すぎるためであることが分った．その対策として次の ことが取り上げられた。

・シリンダ冷却水温度制御装置を改良した。

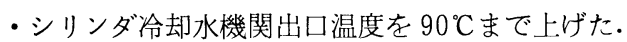

上記対策により 13,000 時間後の開放結果から, 約 0.013 $\mathrm{mm} / 1,000$ 時間の摩耗率にまで回復したことが確認され た．腐食摩耗は高過給機関において将来とあより重大な 問題となるので ( $\mathrm{C}$ 重油中の硫黄分増加, 减速運転等に よる)，乙れに対応するため $\mathrm{C}$ 重油に上る部分負荷運転 要領を発行した (図 18).

一ピストントップリング（クロムメッキ付） 一般的に 平均摩耗率は 0.025 $0.04 \mathrm{~mm} / 1,000$ 時間である.

ーピストン第 2 リング PC 2-5 及び PC 4 形の標準仕 様としてモリブデンコーティングを採用してから，平 均摩耗率は非常に小さく $0.014 \sim 0.016 \mathrm{~mm} / 1,000$ 時間 である. 一方, 銅メッキリングを $\mathrm{PC} 2-5$ 形に使用し た場合は, 約 $0.08 \mathrm{~mm} / 1,000$ 時間と増えている.

以上に示した数值からピストンの定期開放点検間隔は 推奨どおり 12,000 時間にて計画でき,ピストンリングの
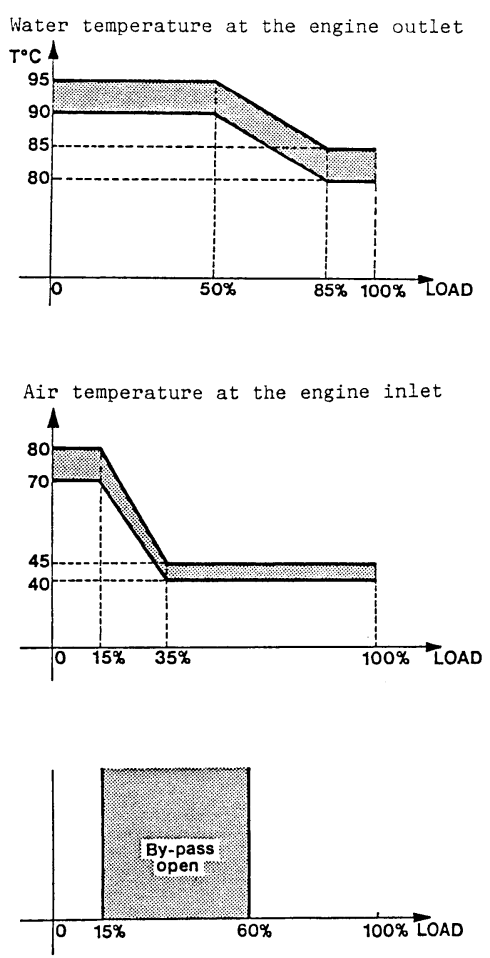

困 18 C重油による部分負荷運転に対する指針

摩耗が低レベルにある場合は更に延長することあ可能で ある. 鋼鉄ピストン冠を有する組立形ピストンのリング 溝の補修(クロムメッキ) は通常 30〜50,000 時間でとに 行われている.

以上から燃料油質の低下にあかかわらず，シリンダラ イナ，ピストンリング等の摩耗值に大きく影響していな いととが分る。効果的な燃料油の清浄は，特に古いプラ ントに扔いて，より困難になることが予想されるが，污 れや燃料噴射弁固着の問題は概して清浄不良に起因する ことが多い，触媒を含有する FCC 油に起因する障害は よく経験するとてろであるが，乙の場合，まず最初に燃 料噴射ポンプが損傷を受け，それにより燃料ラックが増 
加するのでシリンダライナにまで重大な影響を及ぼす前 に予知するととができる。

\section{3 潤滑油消費 PC2-5形の潤滑油消費率は一} 般的に約 $0.8 \mathrm{~g} / \mathrm{PS}-\mathrm{h}$ である (正確に把握できない要因 による損失を含む全消費率). この数值は組立型ピスト ン及び鋳鉄製一体形ピストンのいずれにあ当てはまる. PC 4 形に関する限り潤滑油消費率の平均值は $0.9 \mathrm{~g} / \mathrm{PS}$ -hであるが，乙れには特定の機関での高い潤滑油消費 (2g/PS-h)の分も含まれている.乙れらの高潤滑油消 費機関分を除外すれば約 $0.6 \mathrm{~g} / \mathrm{PS}-\mathrm{h}$ になる. 潤滑油消 費率が $1.2 \mathrm{~g} / \mathrm{PS}$ - $\mathrm{h}$ を越えている場合は明らかに不具合 点がある訳で詳細に調査する必要がある.

3.4 排気弁 $\mathrm{PC} 2-5, \mathrm{PC} 2-6, \mathrm{PC} 3, \mathrm{PC} 4$ 及 び PC 4-2 形の排気弁は 1981 年以来, 効果的な弁座冷 却, 一体形長ブッシュ, ガスシール装置, ナイモニック 弁という新標準仕様が採用されている. 新標準仕様は従 来と比べ多少高価ではあるが, 客先からは満足すべき評 価が得られている. 古くから運航されている機関では在 来仕様 (無冷却弁座, 一般耐熱鋼弁)のままで使用されて いる例も多い. ナイモニック弁を採用した標準仕様(ナ イモニック $80 \mathrm{~A}$, 弁シート部表面硬化形)での定期点検 間隔は約 6,000 時間ごとに計画できる. 補修整備による 削り代を考慮に入れると弁棒の寿命は, 硬化層の厚さか ら 15,000-20,000時間と考えられる.

\section{$3.5 P C 4$ 形ピストン冠とシリンダライナの接} 触マーク PC4 形の就航当初からピストン冠とシリ ンダライナとの強い当りマークが注目されていたが，ほ とんどの場合に掉てピストンリングのシール性及びラ イナ摩耗に悪影響を及ぼさなかった。しかしながら，あ る特定のケースに扔いてての強い当りマークがピストン スカッフィングに関与しているあのと推測された. この 点から特殊な運転状態をむ考慮に入れてスカッフィング に対する安全率を上げる必要がでてきた. 1984 年の前 半に導入したPC 4 形ピストンの改造は上記理由による あので改造点はピストンスカート部の強制注油, ピスト ン油落し孔の一部塞栓及びピストン冠プロフィールの 修正であった。 上記のピストン改造は S. E. M. T. 社の $4 \mathrm{PC} 4 \mathrm{~V}$ 形テストエンジンによる広範囲のテスト結果に 基づき決められた.すなわち，

1）ピストンスカッフィングを再現させる手段を見い 出すために油かきリングの下部，ピストンスカートの円 周に潤滑性を阻害する油溝を加工した. これは不利な運 転条件の組合せ (過負荷, 燃料噴射弁不良, ピストン冠内 面冷却阻害) だけではスカッフィングを再現できなかっ たからである。

2）不利な運転条件下でもスカッフィングを防止する 改良策を見い出すことである.

ピストン焼付きの再現テスト及び改良策の有効性確認 テストは繰返し数回行われた。偏摩耗限界を越えた古い ライナを使用したテストにおいてもこの対策の有効性が
立証された. 約 1 年間継続して行われたてれらのテスト により運転中の諸問題を究明することができ, 有効な解 決策を見い出すことができた. 機関が熱的に過酷な状態 （例えば, 急激な負荷上昇, 低回転で高トルク, 空気量 不足等) で運転された時にピストン冠上部とシリンダラ イナとの強い接触が繰返し発生するとき, 潤滑状態を悪 化させピストン焼付きの起点となりうることが判明した. これらのテストにより安全に対する余裕を大きくできた だけでなく，われわれのスカッフィングに対する知識も 深められ，必要に応じて故障診断装置を開発することあ 可能となった.

3.6PC2-6 形の運航実績 約 40台のPC26 形が就航しており, 最長のものは就航後 2 年半に達す る. 12,000 時間の定期点検時期に達していない機関がほ とんどであり検査記録は少ないが，報告を受けたあのか ら判断する限り非常に良好な運航成績を得ている. ある 日本のライセンシーによれば，シリンダライナ摩耗率は $0.012 \sim 0.024 \mathrm{~mm} / 1,000$ 時間であり, 最小は $0.003 \mathrm{~mm}$ 最大 $0.036 \mathrm{~mm}$ である(調查シリンダ数：38). 平均潤滑 油消費率は $0.7 \mathrm{~g} / \mathrm{PS}-\mathrm{h}$ (調査機関, 11 台), 排気弁の損 傷報告は受けていない.

\section{4. 将来への展望}

新しいPC形機関シリーズ, PC 20, 30, 40 形の出力 範囲は単機の L形機関で 4,000 からほぼ 15,000 PS まで 得られ，更に表 3 に示す低燃料消費率 (85\% MCR にて) を達成することにより市場の要求に完全に適合するもの と確信する(図 19).なお, 新シリーズ機関においても伝 統的な 4 サイクルギャードディーゼルの利点はそのまま 継承されているすすなわち， ーイニシャルコストが低い.

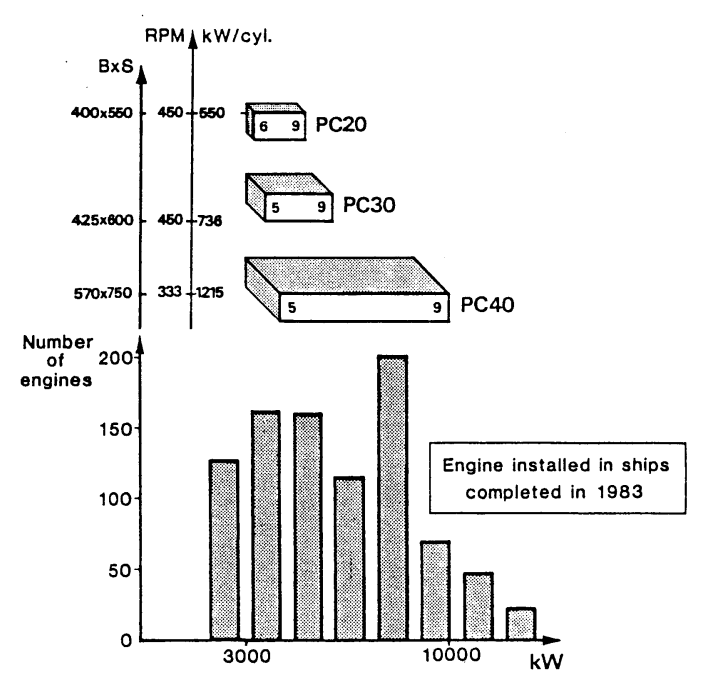

図 19 新形 $\mathrm{PC}$ 機関の出力範囲之 1983 年 建造船搭載の機関実績 
ーコンパクトである(ピストン引抜き高さにストローク 増加の影響がない).

一機関駆動補機が装備可能である.

一機関駆動発電機の装備が容易である.

一廃熱回収の可能性は今までどおり有利である(過給機 出口排ガス温度は約 $350^{\circ} \mathrm{C}$ あるので機関定格出力が 9,000 PS以上あれば通常の船で排ガスターボ発電が可 能).

（文責 栄家達也）

\section{〔質 疑 応 答〕}

質問者 東海汽船(株) 大川一昭

〔質問〕 1. ナイモニック排気弁のシート部の仕様に ついてお尋ねしたい.

2. ナイモニック弁の寿命は 15,000〜20,000 時間との ことであるが, どのように補修を行うのですか.

[回答〕 1. ナイモニック $80 \mathrm{~A}$ という弁棒材料を使 用し, シート部はビッカース硬度 400 に硬化し, その深 さは $3 \mathrm{~mm}$ です.

2. 20,000 時間というのは焼損による寿命ではなく, 6,000 時間ごとの定期点検にて削正するので，その削正 限界によるものである. 即ち, 1 回の削正深さは $0.4 \sim 0.5$ mm 位なので約 20,000 時間で削り代が無くなるためで ある.なお，3,000 時間位で開放してみると少しアバタ状 になっていることがあるが，てれは別に問題なく，余り 頻々と削正しない方が寿命上好ましい.

質問者 阪神内燃機工業(株) 堀 雄一

〔質問〕LeDisez 氏にお尋ねします。ボア/ストロー ク比を大きくし，回転数を下げることによって燃費を下 げているが，その理論的根拠を尋ねたい，又，その効率 はどの程度改善されるか.

〔回答〕作動サイクル後半の定温膨張領域で効率が改 善されるからで, その効率は同一 $P_{\max }$ で約 $6 \%$ 改善さ れ， $P_{\max }$ を上げれば更に良くなる.

質問者 ダイハツディーゼル(株) 瀬角憲一

〔質問〕ロングストローク機関の騷音振動レベルは従 来の PC 機関と比較してどうか. 又, 冷却方式を変えた 燃料弁先端の温度レベルはどの程度か.

〔回答〕テストエンジン (2PC2-6, 4 PC 30 形)では 適当なカウンタウエイトを設けたので，バランスは同程 度に保たれており，振動的に悪くなっていない，PA6 CL形ロングストローク機関では, 騷音はPA6より 2 $\mathrm{dB}$ 低い, 燃料弁先端の温度は PC 2-6 形テストエンジ ンの無冷却弁では 200〜 $230^{\circ} \mathrm{C}$ である. 